\title{
Effectiveness of Using Chicken Manure and Organic Liquid Fertilizer in Ciplukan Plant Cultivation (Physalis angulata L.)
}

\author{
Srie Juli Rachmawatie*, Tri Rahayu, Pramono Hadi, Denny Irawati \\ Faculty of Agriculture, Universitas Islam Batik, Surakarta, 57147, Central Java, Indonesia
}

Received June 17, 2021; Revised September 3, 2021; Accepted September 26, 2021

\section{Cite This Paper in the following Citation Styles}

(a): [1] Srie Juli Rachmawatie, Tri Rahayu, Pramono Hadi, Denny Irawati, "Effectiveness of Using Chicken Manure and Organic Liquid Fertilizer in Ciplukan Plant Cultivation (Physalis angulata L.)," Food Science and Technology, Vol. 9, No. 4, pp. 69-76, 2021. DOI: 10.13189/fst.2021.090401.

(b): Srie Juli Rachmawatie, Tri Rahayu, Pramono Hadi, Denny Irawati (2021). Effectiveness of Using Chicken Manure and Organic Liquid Fertilizer in Ciplukan Plant Cultivation (Physalis angulata L.). Food Science and Technology, 9(4), 69-76. DOI: 10.13189/fst.2021.090401.

Copyright $\mathrm{C} 2021$ by authors, all rights reserved. Authors agree that this article remains permanently open access under the terms of the Creative Commons Attribution License 4.0 International License

\begin{abstract}
The ciplukan plant is a herbal medicinal plant for improving digestion, anti-inflammatory, disinfectant, asthma, whooping cough, bronchitis, orchitis, ulcers, ulcers, cancer, tumours, leukaemia, and diabetes. Optimal cultivation of ciplukan plants is needed to see the benefits obtained for health. This study aims to determine the effectiveness of using chicken manure and Organic Liquid Fertilizer (OLF) to cultivate ciplukan (Physalis angulata $L$.) plants. This study is a completely randomized factorial experimental study (CRD) with two factors and three replications. The treatment factor consisted of two factors: the use of chicken manure and OLF with three replications. Parameters in the study included plant height, number of leaves, wet bottom stover, the weight of dry bottom stover, number of fruits, and fruit weight. ANOVA analysis was carried out to determine the effect of chicken manure and OLF and continued with the 5\% DMRT test on significantly different results. The results showed that chicken manure and OLF had a very significant effect on all observation parameters. The best growth in the $\mathrm{A}_{2} \mathrm{C}_{2}$ treatment was plant height $74.67 \mathrm{~cm}$. The best crop yields were in the $\mathrm{A}_{2} \mathrm{C}_{2}$ treatment with an average number of 37 fruits and average fruit weight of 780 grams per plant.
\end{abstract}

Keywords Organic Fertilizer, Chicken Manure, Organic Liquid Fertilizer, Ciplukan, Health

\section{Introduction}

Ciplukan (Physalis angulata L.) is a plant that is widely found in tropical and subtropical areas. Ciplukan is one of the Indonesian plants proven to have anti-cancer activity [1]. In Indonesia, this plant is still few who use it and cultivate it. This plant, in Java, usually grows wild in gardens, dry fields, roadsides, and forests. Usually, these plants are traded as ingredients for traditional medicine in the form of a single herb or simplicia. Ciplukan has uses in traditional medicine and the potential for the growth of small fruits [2]. All parts of the ciplukan plant, such as leaves, fruit, stems, and roots, are used for herbal drinks [3], [4]. Natural plant products are becoming important in helping promote health around the world [5]. Education about organic food is essential for the community to maintain health [6]. Knowledge of food safety has an essential role in guiding health practice [7]. Ciplukan plants are still mostly taken from plants that grow wild and are not cultivated intensively. The introduction of herbal plants is needed to increase public understanding to create general health [8]. Plants are a source of obtaining materials to overcome various human health problems [9]. Herbal plants need to be developed for commercial and economic purposes [10]. Business sustainability will affect several factors of facilities, capabilities, and production obtained so that it affects the economy of farmers [11].

Ciplukan plants have properties that are used to treat various diseases and have been proven empirically and 
medically. Even in countries such as Brazil, India, Japan, America, Colombia, Peru, Taiwan, Trinidad, Suriname, Elsalvador, conducting medical research for the efficacy of this plant and proven ciplukan plant can treat various diseases. Ciplukan is eaten because of its high nutritional content, and various parts of the plant are also used for medicinal purposes [12]. Despite its many benefits, many people still lack information about this plant and its use for health. Healthy food can affect the health of the family at home [13]. Ciplukan is one type of plants that local Indonesian people have long used as medicine [14], [15]. Many people do not know the benefits of the ciplukan plant, so it is often removed because it is considered a nuisance plant when it grows in the yard, rice field, or garden. This plant is often removed and eradicated using chemicals so that it is currently rarely found growing in gardens, rice fields, or yards. Parts of ciplukan such as leaves, have various pharmacological activities, and the fruit can be used as human food [16]. However, the efficacy of this plant is very much good from the roots, leaves, and fruit itself. The root of the ciplukan plant is generally used as an anthelmintic and fever reducer. The leaves heal broken bones, water swelling, boils, ulcers, heart-strengthening, sprains, abdominal pain, and gonorrhea. Ciplukan leaves are widely used for wound treatment [17]. Ciplukan fruit is often eaten to treat epilepsy, inability to urinate, diabetes, and jaundice [18].

Plant growth is influenced by two factors, namely internal factors, and external factors. Internal factors come from the plant itself, while external factors come from outside the plant, fertilization. Fertilization serves to improve soil quality so that plant productivity can increase. Therefore, the addition of nutrients to ciplukan will support greater production [19].

Manure is an organic fertilizer from the fermentation of solid or liquid manure (urine), generally from mammals or poultry. Organic fertilizers, such as chicken manure, have advantages in improving soil physical properties such as soil permeability, soil porosity, soil structure, and soil cations. In addition, manure also plays a role in increasing the absorption and holding capacity of the soil to water so that the availability of water needed by plants is fulfilled [20]. The nutrient content in chicken manure is $1.7 \% \mathrm{~N}$, $1.90 \% \mathrm{P} 205$, and $1.50 \% \mathrm{~K}_{2} \mathrm{O}$.

Another factor that affects plant growth is Organic Liquid Fertilizer (OLF). The plants themselves easily absorb OLF in their application to plants. Organic Liquid Fertilizer is usually made from waste materials, such as vegetables, tofu, fish, etc. Nutrient content of OLF from banana peels and eggshells: Nitrogen (N) 0.89\%; Phosphorus (P) $0.04 \%$ and Potassium (K) $1.82 \%$. The content of OLF from molasses is $60 \mathrm{ml}$ and fermented for seven days. Nitrogen $(\mathrm{N})$ is $0.339 \%$, Phosphorus (P) is $0.067 \%$ and Potassium $(\mathrm{K})$ is $0.127 \%$.

Rural communities rely heavily on herbal resources to cure diseases [21]. The community needs to preserve local medicinal plants for future generations to support health [22]. The importance of ciplukan plants for herbal medicinal needs must be cultivated organically. So this study aims to determine the effect of using manure and OLF to grow ciplukan plants. The use of organic fertilizers is expected to influence production and health benefits.

\section{Research methods}

This research is an entirely randomized factorial experimental study (CRD) with two factors and three replications. The study was carried out in Dukuh Kantil, Teras Village, Teras Subdistrict, Boyolali Regency with an altitude of $220 \mathrm{~m}$ above sea level. Research materials include ciplukan plant seeds, chicken manure, and OLF. The tools used include Seedling tub, $20 \mathrm{~cm} \times 40 \mathrm{~cm}$ polybag, measuring cup, digital scale, bucket and stirrer, cheers, stationery (book, ballpoint pen, ruler) nameplate/label.

The treatment factor consisted of two factors and three replications. Description of the treatment of the two factors and three replications in the study as follows:

$\mathrm{A}_{0} \mathrm{C}_{0}$ : chicken manure 0 ton/ha and OLF $0 \mathrm{cc}$.

$\mathrm{A}_{0} \mathrm{C}_{1}$ : chicken manure 0 ton/ha and OLF $10 \mathrm{cc}$.

$\mathrm{A}_{0} \mathrm{C}_{2}$ : chicken manure 0 ton/ha and OLF $15 \mathrm{cc}$.

$\mathrm{A}_{1} \mathrm{C}_{0}$ : chicken manure 10 ton/ha and OLF $0 \mathrm{cc}$.

$\mathrm{A}_{1} \mathrm{C}_{1}$ : chicken manure 10 ton/ha and OLF $10 \mathrm{cc}$.

$\mathrm{A}_{1} \mathrm{C}_{2}$ : chicken manure 10 ton/ha and OLF $15 \mathrm{cc}$.

$\mathrm{A}_{2} \mathrm{C}_{0}$ : chicken manure 20 ton/ha and OLF $0 \mathrm{cc}$.

$\mathrm{A}_{2} \mathrm{C}_{1}$ : chicken manure 20 ton/ha and OLF $10 \mathrm{cc}$.

$\mathrm{A}_{2} \mathrm{C}_{2}$ : chicken manure 20 ton/ha and OLF $15 \mathrm{cc}$.

Parameters observed in the study were plant height, number of leaves, wet stover, the weight of dry stover, number of fruit, and fruit weight. This study used an experimental method, with the basic pattern of Completely Randomized Design (CRD) followed by a 5\% DMRT test with significantly different results. 


\section{Result and Discussion}

\subsection{The Effectiveness of Using Chicken Manure and OLF on Plant Height}

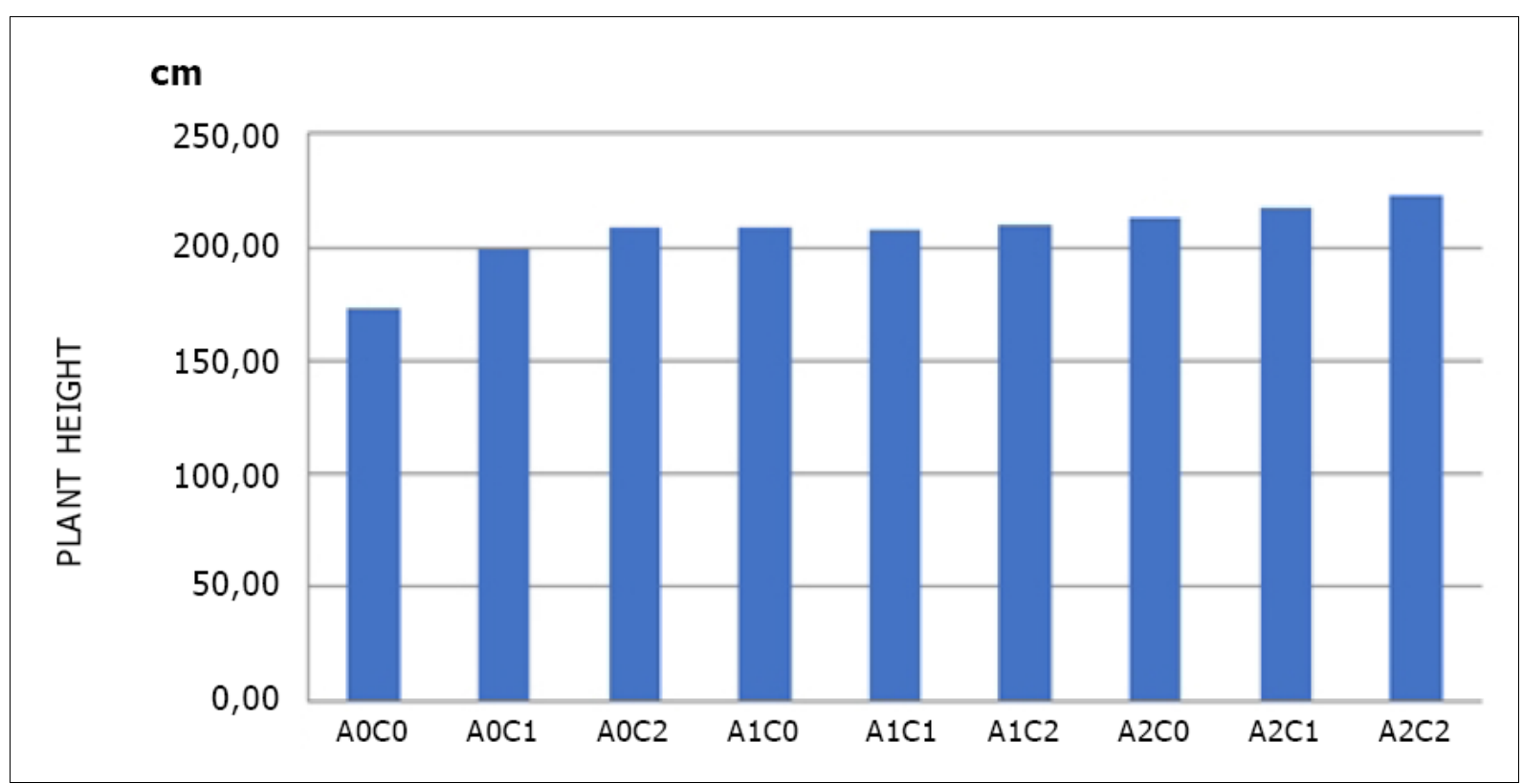

Figure 1. Histogram of Plant height

In Figure 2, the highest ciplukan plant height was $(74.67 \mathrm{~cm})$, obtained from the combination of $\mathrm{A}_{2} \mathrm{C}_{2}$ treatments (manure dose 20 tons/ha and POC $15 \mathrm{cc}$ ). Conversely, the lowest ciplukan plant height was $(55.33 \mathrm{~cm}$ ), obtained in the combination treatment $\mathrm{A}_{0} \mathrm{C}_{0}$.

\subsection{The Effectiveness of Using Chicken Manure and OLF on the Number of Leaves}

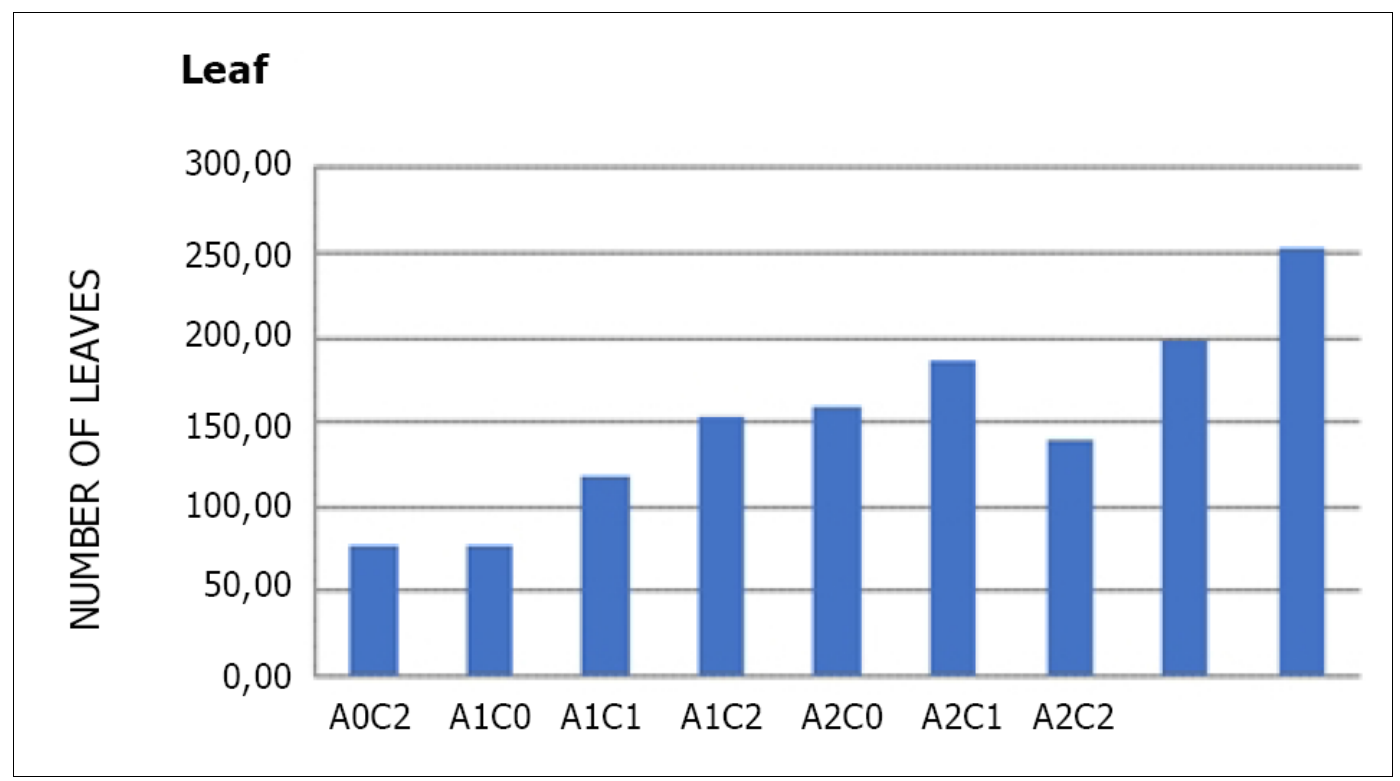

Figure 2. Histogram of Leave Number

In Figure 2, the highest number of leaves of ciplukan plants, namely ( 85.67 strands), was obtained in the combination of $\mathrm{A}_{2} \mathrm{C}_{2}$ treatments (dose of manure 20 tons/ha and POC $15 \mathrm{cc}$ ). On the other hand, the smallest number of leaves of the ciplukan plant (21.67 pieces) was obtained in the $\mathrm{A}_{0} \mathrm{C}_{0}$ treatment combination. 


\subsection{The Effectiveness of Using Chicken Manure and OLF on Plant Wet Weight}

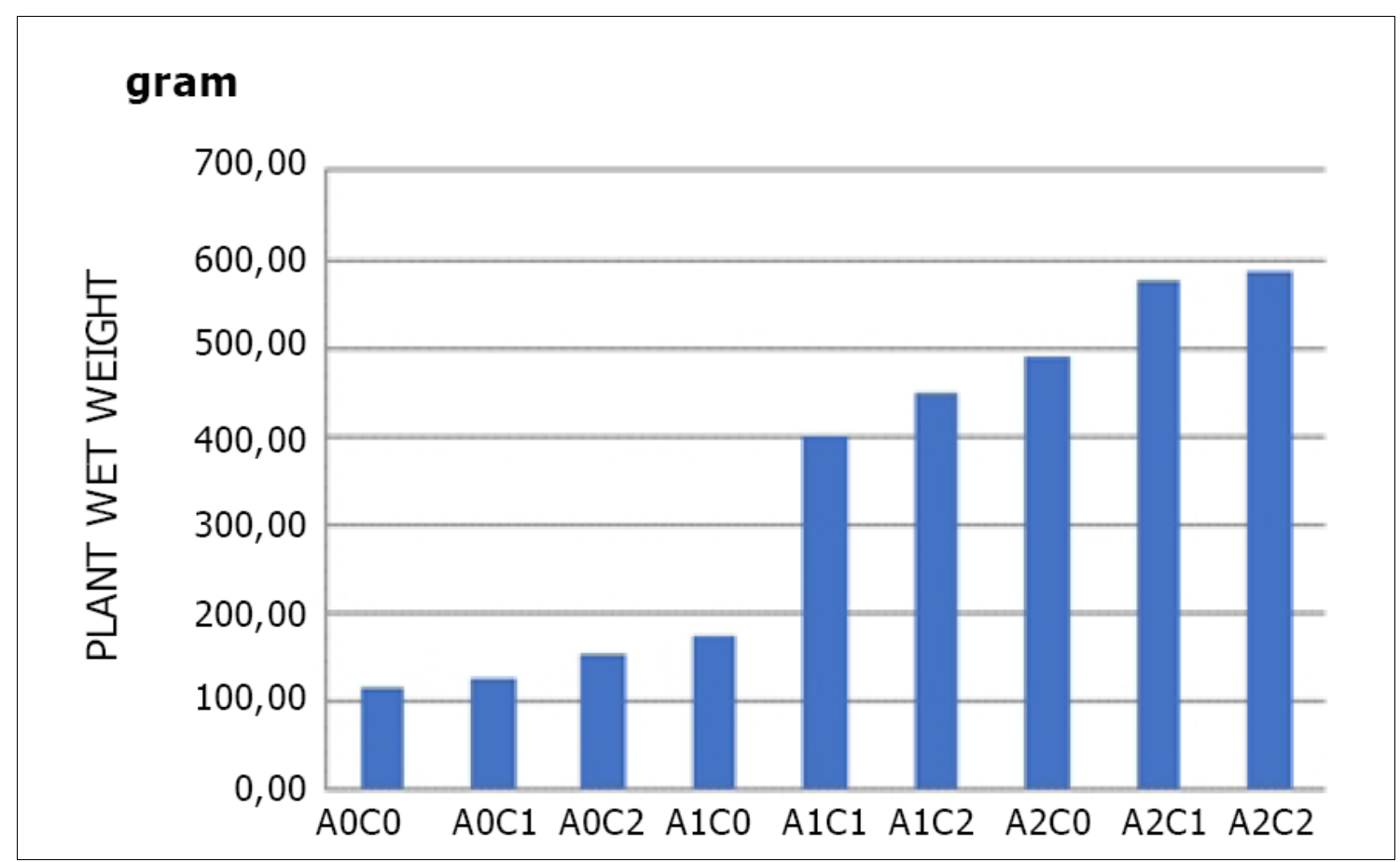

Figure 3. Histogram of Plant Wet Weight

In Figure 3, the highest ciplukan wet plant weight, namely (198.33 grams), was obtained in the $\mathrm{A}_{2} \mathrm{C}_{2}$ treatment combination. On the other hand, the lowest wet weight of the ciplukan plant was (36.00 grams), obtained in the combination of $\mathrm{A}_{0} \mathrm{C}_{0}$ treatment.

\subsection{The Effectiveness of Using Chicken Manure and OLF on Plant Dry Weight}

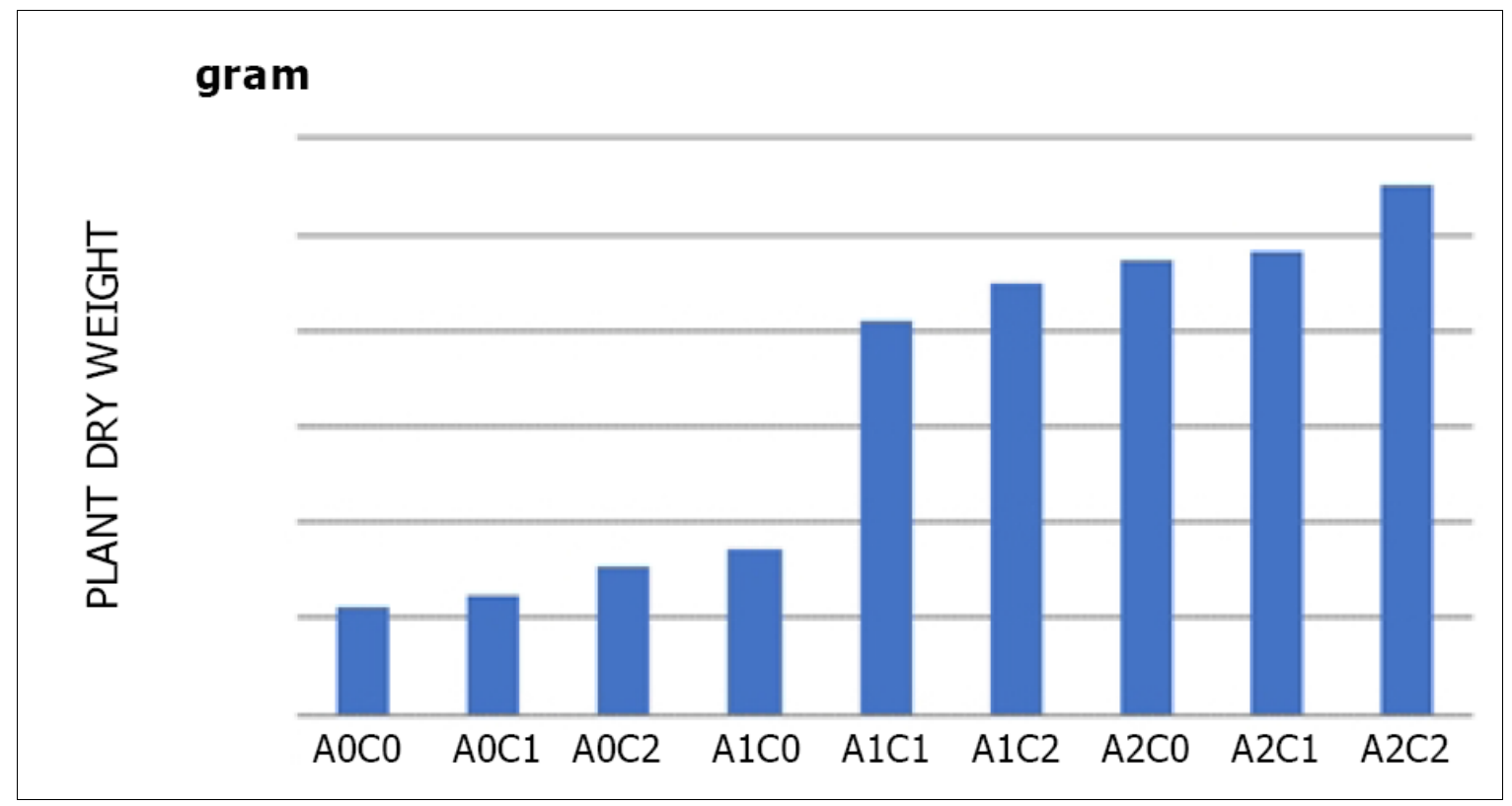

Figure 4. Histogram of Plant Dry Weight

In Figure 4, the highest dry plant weight of ciplukan (95.33 grams) was obtained in the $\mathrm{A}_{2} \mathrm{C}_{2}$ treatment combination. Conversely, the lowest dry weight of the ciplukan plant (17.33 grams) was obtained in the combination of $\mathrm{A}_{0} \mathrm{C}_{0}$ treatment. 


\subsection{The Effectiveness of Using Chicken Manure and OLF on the Number of Fruits}

\section{Fruit}

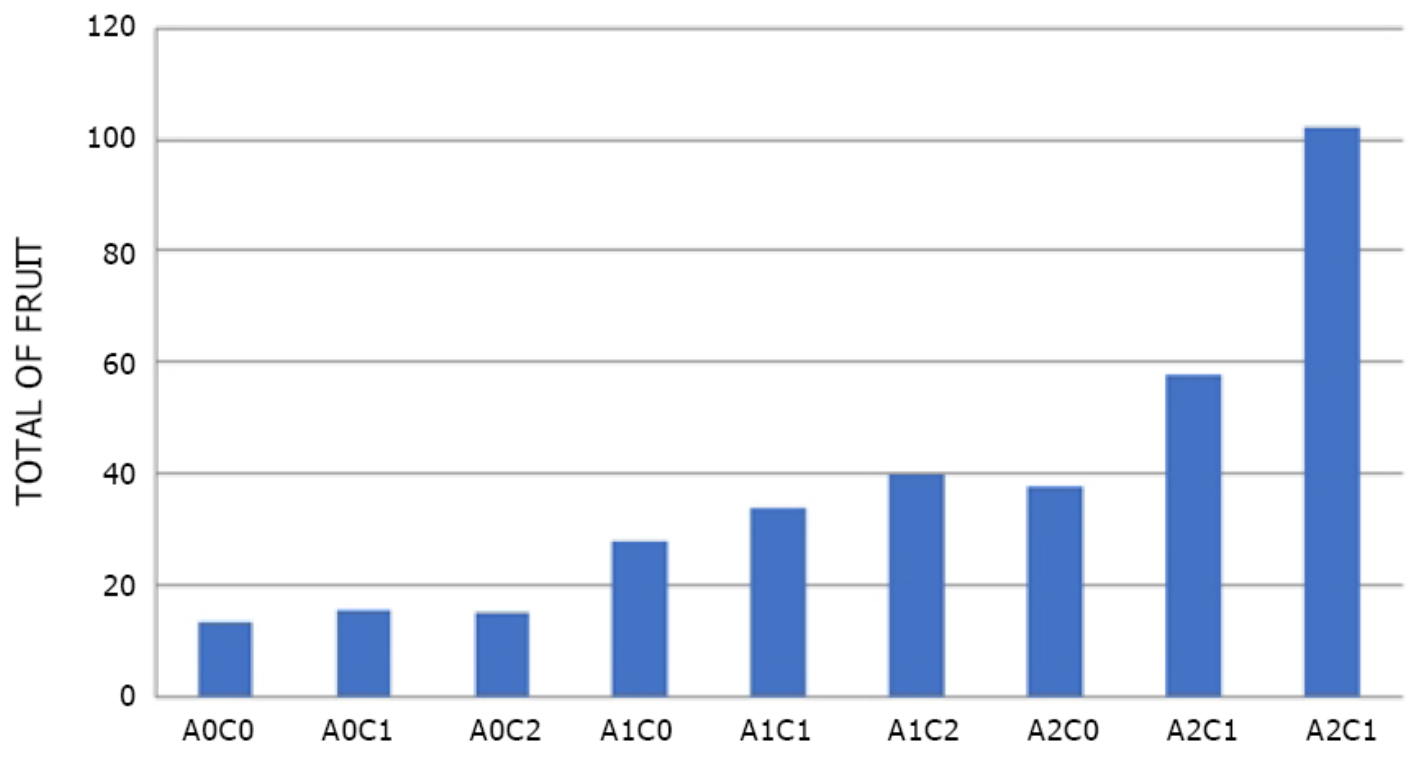

Figure 5. Histogram of Fruit Number

In Figure 5, the highest number of ciplukan fruit (37 pieces) was obtained in the $\mathrm{A}_{2} \mathrm{C}_{2}$ treatment combination. On the other hand, the lowest ciplukan fruit (4 pieces) was obtained in the $\mathrm{A}_{0} \mathrm{C}_{0}$ treatment combination.

\subsection{The Effectiveness of Using Chicken Manure and OLF on Fruit Weight}

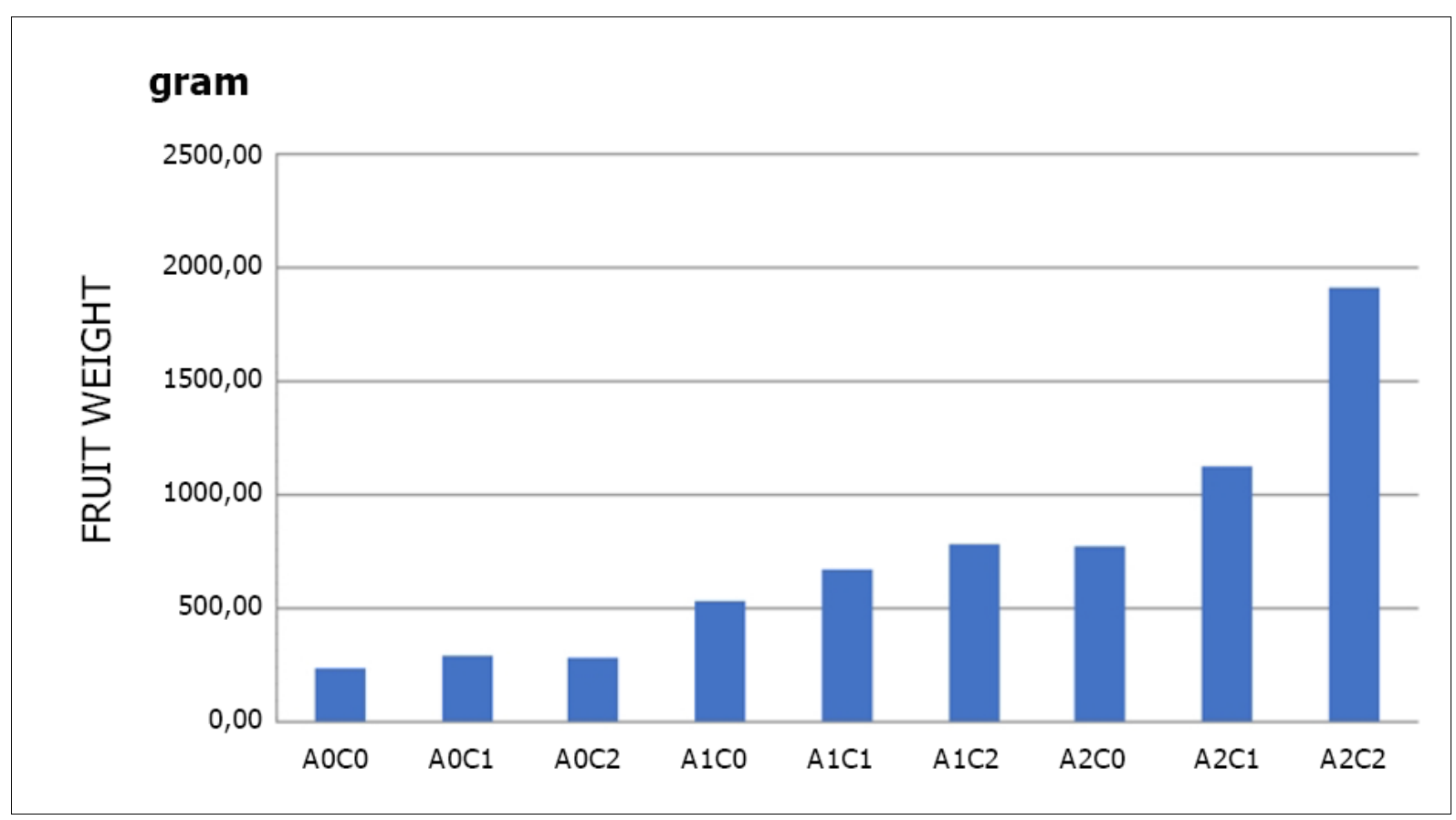

Figure 6. Histogram of Fruit Weight

In Figure 6, the highest ciplukan fruit weight ( 730 grams) was obtained in the $\mathrm{A}_{2} \mathrm{C}_{2}$ treatment combination. Conversely, 
the lowest ciplukan fruit weight (63.33 grams) was obtained in the $\mathrm{A}_{0} \mathrm{C}_{0}$ treatment combination.

\subsection{Test DMRT}

The results of the further CRD test showed significantly different values, then proceeded to the DMRT test. The results of the 5\% DMRT test in the study can be seen in table 1 .

Table 1. The resume yield of the research.

\begin{tabular}{|c|c|c|c|c|c|c|}
\hline \multirow{2}{*}{ No } & \multirow{2}{*}{ Parameter } & \multirow{2}{*}{ Chicken Manure } & \multicolumn{3}{|c|}{ Concentration OLF } & \multirow{2}{*}{ Average } \\
\hline & & & $\mathrm{C}_{0}$ & $\mathrm{C}_{1}$ & $\mathrm{C}_{2}$ & \\
\hline \multirow[t]{17}{*}{1} & \multicolumn{6}{|c|}{ Plant growth } \\
\hline & \multirow[t]{4}{*}{ a. Plant height $(\mathrm{cm})$} & $\mathrm{A}_{0}$ & $57.56 \mathrm{a}$ & $66.22 \mathrm{~b}$ & $69.44 b$ & $64.40 \mathrm{a}$ \\
\hline & & $\mathrm{A}_{1}$ & $69.56 \mathrm{~b}$ & $69.33 b$ & $70.11 \mathrm{c}$ & $69.66 \mathrm{~b}$ \\
\hline & & $\mathrm{A}_{2}$ & $71.00 \mathrm{c}$ & $72.44 \mathrm{c}$ & $74.44 \mathrm{~d}$ & $72.62 \mathrm{c}$ \\
\hline & & Average & $66.04 \mathrm{a}$ & $69.33 b$ & $71.33 \mathrm{c}$ & \\
\hline & \multirow[t]{4}{*}{ b. Number of leaves (Sheet) } & $\mathrm{A}_{0}$ & $25.44 \mathrm{a}$ & $25.67 \mathrm{a}$ & $39.44 \mathrm{~b}$ & $30.18 \mathrm{a}$ \\
\hline & & $\mathrm{A}_{1}$ & $51.00 \mathrm{~b}$ & $53.11 \mathrm{~b}$ & $62.11 \mathrm{c}$ & $55.40 \mathrm{~b}$ \\
\hline & & $\mathrm{A}_{2}$ & $46.56 \mathrm{~b}$ & $66.00 \mathrm{c}$ & $84.33 \mathrm{~d}$ & $65.63 \mathrm{c}$ \\
\hline & & Average & $41.00 \mathrm{a}$ & $57.37 \mathrm{~b}$ & $61.96 \mathrm{c}$ & \\
\hline & \multirow[t]{4}{*}{ c. Plant Wet Weight (gram) } & $\mathrm{A}_{0}$ & $38.56 \mathrm{a}$ & $41.44 \mathrm{a}$ & $51.00 \mathrm{a}$ & $43.66 \mathrm{a}$ \\
\hline & & $\mathrm{A}_{1}$ & $57.44 \mathrm{a}$ & $133.89 \mathrm{~b}$ & $150.11 \mathrm{~b}$ & $113.81 \mathrm{~b}$ \\
\hline & & $\mathrm{A}_{2}$ & $163.56 \mathrm{c}$ & $192.00 \mathrm{~d}$ & $195.33 d$ & $183.63 \mathrm{c}$ \\
\hline & & Average & $86.52 \mathrm{a}$ & $122.44 \mathrm{~b}$ & $132.14 \mathrm{c}$ & \\
\hline & \multirow[t]{4}{*}{ d. Plant dry Weight (gram) } & $\mathrm{A}_{0}$ & $18.89 \mathrm{a}$ & $20.56 \mathrm{a}$ & $25.56 \mathrm{a}$ & $21.67 \mathrm{a}$ \\
\hline & & $\mathrm{A}_{1}$ & $28.56 b$ & $68.22 \mathrm{c}$ & $74.89 \mathrm{c}$ & $57.22 \mathrm{~b}$ \\
\hline & & $\mathrm{A}_{2}$ & $78.78 \mathrm{c}$ & $80.22 \mathrm{~d}$ & $92.11 \mathrm{~d}$ & $83.70 \mathrm{c}$ \\
\hline & & Average & $42.07 \mathrm{a}$ & $56.33 \mathrm{~b}$ & $64.18 \mathrm{c}$ & \\
\hline \multirow[t]{9}{*}{2} & \multicolumn{6}{|c|}{ Plant production } \\
\hline & \multirow[t]{4}{*}{ a. number of fruit } & $\mathrm{A}_{0}$ & $4 \mathrm{a}$ & $5 \mathrm{a}$ & $5 \mathrm{a}$ & $4.6 \mathrm{a}$ \\
\hline & & $\mathrm{A}_{1}$ & $9 \mathrm{a}$ & $11 \mathrm{ab}$ & $13 \mathrm{c}$ & $11 \mathrm{~b}$ \\
\hline & & $\mathrm{A}_{2}$ & $13 \mathrm{c}$ & $19 \mathrm{~d}$ & $34 \mathrm{e}$ & $22 \mathrm{c}$ \\
\hline & & Average & $8.66 \mathrm{a}$ & $11.66 \mathrm{~b}$ & $17.33 \mathrm{c}$ & \\
\hline & \multirow[t]{4}{*}{ b. fruit weight (gram) } & $\mathrm{A}_{0}$ & 80 & 98 & 96 & $91.33 \mathrm{a}$ \\
\hline & & $\mathrm{A}_{1}$ & 178 & 224 & 261 & $221 \mathrm{~b}$ \\
\hline & & $\mathrm{A}_{2}$ & 259 & 377 & 639 & $425 \mathrm{c}$ \\
\hline & & Average & $172.33 \mathrm{a}$ & $233 b$ & $332 \mathrm{c}$ & \\
\hline
\end{tabular}

The treatment using doses of chicken manure had a very significant effect on all observation parameters. The purpose of treatment using chicken manure is to overcome nutrient deficiencies, especially nitrogen $(\mathrm{N})$, phosphorus $(\mathrm{P})$, and potassium $(\mathrm{K})$ which are micronutrients that play an essential role in plant growth and production. Chicken manure organic fertilizer has a high nitrogen content [23]. The availability of $\mathrm{N}, \mathrm{P}$, and $\mathrm{K}$ in the soil is the most limiting factor in obtaining maximum cultivated plants' growth and yield. Organic fertilizers provide sufficient nutrients and improve the soil environment [24]-[26]. The use of OLF has a very significant effect on all observation parameters. The purpose of treatment using OLF is to balance essential nutrients needed by plants for plant production. Organic Liquid fertilizer has a positive impact on plant growth [27], [28]. In this study, it is hoped that OLF concentration can be obtained, increasing optimal plant productivity. The sensitivity level of OLF can affect the permeability of leaf cells and determine how much or how plants can absorb little nutrients so that OLF impacts whether or not optimal plant growth. Each treatment has different effects to improve organic matter and its physical properties [29].

The treatment of using chicken manure and OLF had a 
very significant effect on all observation parameters. The combination of treatments (OLF and manure) supported the vegetative and generative growth of ciplukan plants. Chicken manure applied through soil media can help meet the availability of soil nutrients and help improve soil structure so that it can be a good growing medium for plants. Nutrient content in livestock manure that is important for plants includes elements of Nitrogen $(\mathrm{N})$, Phosphorus (P), and Potassium (K). Plants most need these three elements. Each of these nutrients has a different and complementary function for plants. Thus growth becomes optimal. Organic Liquid Fertilizer applied through the soil can directly meet the nutrient needs of plants to be used in the photosynthesis process.

\section{Conclusions}

The application of chicken manure had a significant effect on the six research parameters. Organic Liquid Fertilizer administration has a significant effect on the six research parameters. The application of a combination of chicken manure and OLF significantly affected the six research parameters. The existence of organic fertilizers is expected to increase production and provide benefits for humans. Therefore, organic ciplukan is expected to positively influence farmers who cultivate economically, socially, and healthily.

\section{Acknowledgments}

The researcher would like to thank the Universitas Batik (UNIBA) Surakarta for the support and support so that this research can be completed and published in journals

\section{REFERENCES}

[1] Maryati, Sutrisna, Saifudin, Saifudin, and Abu Bakar, 'Extract of ceplukan (Physalis angulata L.) inhibited proliferation and induced apoptosis in myeloma cell line', Food Res., vol. 3, no. 6, pp. 755-760, 2019, doi: 10.26656/fr.2017.3(6).169.

[2] R. da Silva Leite, M. N. do Nascimento, T. T. Tanan, L. P. Gonçalves Neto, C. A. da Silva Ramos, and A. L. da Silva, 'Alleviation of water deficit in Physalis angulata plants by nitric oxide exogenous donor', Agric. Water Manag., vol. 216, pp. 98-104, May 2019, doi:

10.1016/j.agwat.2019.02.001.

[3] R. Luthfiyanti, A. C. Iwansyah, Y. Rahayu, and N. S. Achyadi, 'Study of antioxidant activities, acceptability, and shelf life prediction of Ciplukan (Physalis angulata L.) juice drinks', in IOP Conference Series: Materials Science and Engineering, Jan. 2021, vol. 1011, no. 1, p. 012001, doi: 10.1088/1757-899X/1011/1/012001.
[4] F. Azima, Novelina, I. Suryanti, and D. Syukri, 'Production of an instant functional beverage made from ciplukan (Physalis angulata L.) with Cassia vera', Pakistan J. Nutr., vol. 17, no. 7, pp. 355-360, Jun. 2018, doi: 10.3923/pjn.2018.355.360.

[5] K. S. Ng, M. Zin, N. Mohdmaidin, H. Mamat, N. H. Juhari, and M. K. Zainol, 'High-performance liquid chromatography (HPLC) analysis for flavonoids profiling of Napier grass herbal tea', J. homepage, vol. 5, no. 1, pp. 65-71, 2021, doi: 10.26656/fr.2017.5(1).311.

[6] W.-J. J. Yen, 'Blog-based Nutrition Education for College Students', Food Science and Technology, vol. 5, no. 1, pp. 37-46, Jan. 2017, doi: 10.13189/fst.2017.050103.

[7] A. A. Abdelhakeem, B. Feyza, and A.-A. Hekmat, 'Food Safety Knowledge among Food Handlers in Hospitals of Jordan', Food Science and Technology, vol. 9, no. 2, pp. 17-30, Jun. 2021, doi: 10.13189/fst.2021.090201.

[8] M. S. Amjad, U. Zahoor, R. W. Bussmann, M. Altaf, S. M. H. Gardazi, and A. M. Abbasi, 'Ethnobotanical survey of the medicinal flora of Harighal, Azad Jammu \& Kashmir, Pakistan', J. Ethnobiol. Ethnomed., vol. 16, no. 1, pp. 1-28, Dec. 2020, doi: 10.1186/s13002-020-00417-w.

[9] M. M. Taek, G. D. Tukan, B. E. Prajogo, M. Agil, and B. Timor Endonezya Yerel Halkının Kullandığı Bazı Antimalaryal Bitkilerin Antiplazmodiyal Aktiviteleri ve Fitokimyasal Bileşenleri, 'Antiplasmodial Activity and Phytochemical Constituents of Selected Antimalarial Plants Used by Native People in West Timor Indonesia', Turkish J. Pharm. Sci., vol. 18, no. 1, pp. 80-90, 2021, doi: 10.4274/tjps.galenos.2019.29000.

[10] N. S. Zahidin et al., 'Preliminary Study of Potential Herbal Tea, Acalypha indica and Comparison with Domestic Tea in Malaysia Market', Food Science and Technology, vol. 6, no. 1, pp. 41-45, Jan. 2018, doi: 10.13189/fst.2018.060105.

[11] S. R. Ursule et al., 'Socio-economic situation of poultry farmer and the local chicken production system of the east-coast of Madagascar', Universal Journal of Agricultural Research, vol. 8, no. 6, pp. 185-201, 2020, doi: 10.13189/ujar.2020.080601.

[12] C. A. da S. Ramos, T. L. Soares, N. S. Barroso, and C. R. Pelacani, 'Influence of maturity stage on physical and chemical characteristics of fruit and physiological quality of seeds of Physalis angulata L.', Sci. Hortic. (Amsterdam)., vol. 284, p. 110124, Jun. 2021, doi: 10.1016/j.scienta.2021.110124.

[13] J. Setorglo, P. N. Gorleku, B. Setorglo, M. Asomboya, F. N. Arthur, and M. K. Klevor, 'Timely initiation and exclusive breastfeeding rates at adentan municipality in Ghana', Food Science and Technology (United States), vol. 8, no. 1, pp. 1-9, 2020, doi: 10.13189/fst.2020.080101.

[14] T. Hidayat, L. J. Yosnata, L. T. Wulandari, D. Priyandoko, and S. Aisyah, 'Random amplified polymorphism DNA method to authenticate indonesian medicinal plant ciplukan (Physalis angulata; solanaceae)', Pertanika J. Sci. Technol., vol. 25, no. S, pp. 13-22, Nov. 2017.

[15] T. Hidayat, D. Priyandoko, F. S. Perdana, A. M. Insan, and Hernawati, 'Cytotoxicity effects of leaf extracts of Ciplukan (Physalis angulata; Solanaceae) on human blood and ovary cancer cell lines', in Journal of Physics: 
Conference Series, Nov. 2019, vol. 1280, no. 2, doi: $10.1088 / 1742-6596 / 1280 / 2 / 022009$.

[16] M. C. C. Figueiredo, A. R. Passos, F. M. Hughes, K. S. dos Santos, A. L. da Silva, and T. L. Soares, 'Reproductive biology of Physalis angulata L. (Solanaceae)', Sci. Hortic. (Amsterdam)., vol. 267, p. 109307, Jun. 2020, doi: 10.1016/j.scienta.2020.109307.

[17] A. Y. Abdul-Nasir-Deen et al., 'Anti-inflammatory and wound healing properties of methanol leaf extract of Physalis angulata L.', South African J. Bot., vol. 133, pp. 124-131, Sep. 2020, doi: 10.1016/j.sajb.2020.06.030.

[18] T. Q. Nguyen and T. S. Vo, 'Investigation of the anti-diabetic and antioxidant activities of physalis angulata extract', Trop. J. Nat. Prod. Res., vol. 4, no. 6, pp. 243-248, Jun. 2020, doi: 10.26538/tjnpr/v4i6.6.

[19] J. del C. M. Saavedra, F. A. Rodríguez Zaragoza, D. Cabrera Toledo, C. V. Sánchez Hernández, and O. Vargas-Ponce, 'Agromorphological characterization of wild and weedy populations of Physalis angulata in Mexico', Sci. Hortic. (Amsterdam)., vol. 246, pp. 86-94, Feb. 2019, doi: 10.1016/j.scienta.2018.10.055.

[20] R. Chang, Y. Li, Q. Chen, X. Gong, and Z. Qi, 'Effects of carbon-based additives and ventilation rate on nitrogen loss and microbial community during chicken manure composting', PLoS One, vol. 15, no. 9 September 2020, p. e0229880, Sep. 2020, doi: 10.1371/journal.pone.0229880.

[21] M. Kumar et al., 'Implementation of the use of ethnomedicinal plants for curing diseases in the indian himalayas and its role in sustainability of livelihoods and socioeconomic development', Int. J. Environ. Res. Public Health, vol. 18, no. 4, pp. 1-26, Feb. 2021, doi: 10.3390/ijerph18041509.

[22] M. Ishtiaq et al., 'Ethnomedicinal and folklore inventory of wild plants used by rural communities of valley Samahni, District Bhimber Azad Jammu and Kashmir, Pakistan', PLoS One, vol. 16, no. 1 January, p. e0243151, Jan. 2021, doi: 10.1371/journal.pone.0243151.

[23] F. Wang, M. Pei, L. Qiu, Y. Yao, C. Zhang, and H. Qiang, 'Performance of anaerobic digestion of chicken manure under gradually elevated organic loading rates', Int. J. Environ. Res. Public Health, vol. 16, no. 12, p. 2239, Jun. 2019, doi: 10.3390/ijerph16122239.

[24] L. Borrelli and L. Pecetti, 'Wheat yield as a measure of the residual fertility after 20 years of forage cropping systems with different manure management in Northern Italy', Ital. J. Agron., vol. 14, no. 3, pp. 142-146, Jul. 2019, doi: 10.4081/ija.2019.1359.

[25] T. R. de Melo, A. Figueiredo, W. Machado, and J. Tavares Filho, 'Changes on soil structural stability after in natura and composted chicken manure application', Int. J. Recycl. Org. Waste Agric., vol. 8, no. 4, pp. 333-338, Dec. 2019, doi: 10.1007/s40093-019-0250-1.

[26] Y. Geng, G. Cao, L. Wang, and S. Wang, 'Effects of equal chemical fertilizer substitutions with organic manure on yield, dry matter, and nitrogen uptake of spring maize and soil nitrogen distribution', PLoS One, vol. 14, no. 7, p. e0219512, Jul. 2019, doi: 10.1371/journal.pone.0219512.

[27] T. Phibunwatthanawong and N. Riddech, 'Liquid organic fertilizer production for growing vegetables under hydroponic condition', Int. J. Recycl. Org. Waste Agric., vol. 8, no. 4, pp. 369-380, Dec. 2019, doi: 10.1007/s40093-019-0257-7.

[28] V. Antoneli et al., 'Effects of applying liquid swine manure on soil quality and yield production in tropical soybean crops (Paraná, Brazil)', Sustain., vol. 11, no. 14, p. 3898, Jul. 2019, doi: 10.3390/su11143898.

[29] Widowati, Sutoyo, H. Karamina, and W. Fikrinda, 'Soil amendment impact to soil organic matter and physical properties on the three soil types after second corn cultivation', AIMS Agric. Food, vol. 5, no. 1, pp. 150-168, 2020, doi: 10.3934/AGRFOOD.2020.1.150. 